\title{
ADAPTATION AND TRANSCULTURAL VALIDATION OF THE BRAZILIAN VERSION OF THE BACK PAIN FUNCTIONAL SCALE
}

\author{
ADAPTAÇÃO E VALIDAÇÃO TRANSCULTURAL DA VERSÃO BRASILEIRA DA ESCALA \\ FUNCIONAL DE DOR LOMBAR
}

\section{ADAPTACIÓN Y VALIDACIÓN TRANSCULTURAL DE LA VERSIÓN BRASILEÑA DE LA ESCALA FUNCIONAL DE DOLOR LOMBAR}

Jefferson Jovelino Amaral dos Santos, ${ }^{1}$ Franciele luz de Andrade Tiburciom, ${ }^{1}$ Ana Paula Kremer ${ }^{1}$

1. Universidade Paranaense - UNIPAR, Physical Therapy Department, Toledo, PR, Brazil.

\begin{abstract}
Objective: The Back Pain Functional Scale (BPFS) was designed to evaluate the functional state of individuals with low back pain. The scale consists of twelve items, covering functional aspects of the daily life activities of these individuals. The final score is calculated by summing the responses to each item, the values of which range from 0 to 5, obtaining a total result of 0 to 60 points. Methods: The validation process was developed in accordance with the World Health Organization (WHO) protocol, covering translation, back translation, semantic equivalence, evaluation by specialists from previous stages, pre-test of the tool, and final version. Subsequently, the final version was applied in a sample of 90 individuals and the data obtained were subjected to descriptive statistical analysis, factorial analysis, evaluation of internal consistency, and correlation with other validated tools. Results: The tool was adapted to Brazilian Portuguese, making use of terms to approximate the language of everyday expressions. The final version presented results similar to those from the original version, as demonstrated by the factorial analysis, the internal consistency (Cronbach's alpha: 0.990), and the strong correlation with tools validated for the Portuguese language. Conclusion: The Brazilian version of BPFS proved to be easy to apply and understand, and presented high internal consistency and construct validity similar to that of the original instrument. Level of evidence 1B; Study of adaptation of a valid score.
\end{abstract}

Keywords: Low Back Pain; Validation Studies; Functionality; Surveys and Questionnaires; Scales.

\section{RESUMO}

Objetivo: A Escala Funcional de Dor Lombar (EFDL) foi concebida para avaliar o estado funcional de indivíduos acometidos por lombalgia. A escala é constituída por doze itens e abrange aspectos funcionais em atividades de vida diária desses indivíduos. O escore final é calculado pela soma das respostas de cada item, cujo valor varia de 0 a 5, obtendo um resultado total de 0 a 60 pontos. Métodos: 0 processo de validação foi desenvolvido de acordo com o protocolo da Organização Mundial da Saúde (OMS), abrangendo tradução, retrotradução, equivalência semântica, avaliação de especialistas das etapas anteriores, pré-teste do instrumento e versão final. Na sequência, a versão final foi aplicada em uma amostra de 90 indivíduos e os dados obtidos foram submetidos a análise estatística descritiva, análise fatorial, avaliação da consistência interna e correlação com outros instrumentos validados. Resultados: Realizou-se a adequação do instrumento para o português utilizado no Brasil fazendo uso de termos para aproximar a linguagem das expressões do dia a dia. A versão final apresentou resultados similares à versão original, demonstrados pela análise fatorial, pela consistência interna (alfa de Cronbach: 0,990) e pela correlação forte com instrumentos validados para a línqua portuquesa. Conclusões: A versão brasileira da EFDL mostrou ter fácil aplicação e compreensão, apresentou alta consistência interna e similar validade de construto ao instrumento original. Nível de evidência 1B; Estudo de adaptação de um escore válido.

Descritores: Dor Lombar; Estudo de Validação; Funcionalidade; Inquéritos e Questionários; Escalas.

\section{RESUMEN}

Objetivo: La Escala Funcional de Dolor Lumbar (EFDL) fue concebida para evaluar el estado funcional de individuos acometidos por lumbalgia. La escala está constituida por doce ítems y abarca aspectos funcionales en actividades de la vida diaria de estos individuos. La puntuación final es calculada por la suma de las respuestas de cada ítem, cuyo valor varía de 0 a 5, obteniendo un resultado total de 0 a 60 puntos. Métodos: El proceso de validación fue desarrollado de acuerdo con el protocolo de la Organización Mundial de la Salud (OMS), abarcando traducción, retrotraducción, equivalencia semántica, evaluación de especialistas de las etapas anteriores, test previo del instrumento y versión final. A continuación, la versión final fue aplicada en una muestra de 90 individuos y los datos obtenidos se sometieron a análisis estadístico descriptivo, análisis factorial, evaluación de la consistencia interna y correlación con otros instrumentos validados. Resultados: Se realizó la adecuación del instrumento para el portugués utilizado en Brasil haciendo uso de términos para aproximar el lenguaje a las expresiones de la vida cotidiana. La versión final presentó resultados similares a la versión original, demostrados por el análisis factorial, por la consistencia interna (alfa de Cronbach: 0,990) y correlación fuerte con instrumentos validados para el idioma portugués. Conclusiones: La versión brasileña de la EFDL mostró tener fácil aplicación y comprensión, presentó alta consistencia interna y similar validez de constructo al instrumento original. Nivel de evidencia 1B; Estudio de adaptación de una puntuación válida.

Descriptores: Dolor de la Región Lumbar; Estudio de Validación; Funcionalidad; Encuestas y Cuestionarios; Escalas. 


\section{INTRODUCTION}

Low back pain or lumbalgia is a symptom, not a disease, and can result from various known or unknown abnormalities or diseases. It is defined by the location of the pain, typically between the lower margins of the ribs and the gluteal folds. The condition is often accompanied by pain in one or both lower limbs and some people have associated neurological symptoms. ${ }^{1}$

It is a painful condition that can affect up to $65 \%$ of people each year and it is estimated that up to $84 \%$ of people will have low back pain at some point in their life. ${ }^{2}$ It is more prevalent among women and in individuals between 40 and 80 years of age. ${ }^{3}$ Recent data have shown that low back pain has generated an increase in the number of years that sufferers live with disability. ${ }^{4}$ In Brazil the incidence of low back pain is known to be high ( $>50 \%$ ), but the fragility of Brazilian studies may mean that the real numbers for this condition are underestimated. ${ }^{5}$

The costs of managing low back pain are increasing, mainly in low- and medium-income countries that are overburdening health and social systems that are already overburdened. ${ }^{1}$

Measures to prevent the onset of pain and the persistence of disability associated with low back pain demand an awareness that the disability is intimately tied to the social and economic context of those who suffer from it, as well as to personal and cultural beliefs. ${ }^{6}$

In an effort to understand and study low back pain, questionnaires have been widely used as a tool in epidemiological, monitoring, and treatment efficacy analysis studies. ${ }^{2}$ The first studies to use self-administered questionnaires to analyze low back pain were launched in the $1980 \mathrm{~s}^{7}$ and they have since been adapted for use in Brazilian Portuguese..$^{8-10}$

The Back Pain Functional Scale (BPFS) was conceived by Stratford et al. to be used to measure functional status and a tool to assist decision making, both individually and for groups of patients. The scale showed excellent results in relation to its descriptive analysis, internal consistency, reliability, validity, and sensitivity. ${ }^{11}$

Administration and interpretation of the BPFS are extremely practical. It consists of 12 questions with 6 possible responses, each associated with a point value (Likert scale), with 0 being unable to perform the activity, 1 being able to perform the activity with extreme difficulty, 2 with quite a bit of difficulty, 3 with moderate difficulty, 4 with a little bit of difficulty, and 5 with no difficulty. The total score can range from 0 to 60 and the higher the score, the greater the functional capacity of the person being assessed. A score of 0 indicates that the individual is extremely unable to perform any activity and a score of 60 signifies the absence of difficulty in performing any activity.

The objective of this study was the adaptation and validation of the BPFS for Brazilian Portuguese.

\section{METHODS}

To initiate the study, the BPFS authors were asked to authorize its use and adaptation to Brazilian Portuguese, after which it was approved by the Institutional Review Board of the Universidade Paranaense as IRF Consolidated Opinion number 1.698.082.

The translation and back-translation protocol recommended by the World Health Organization (WHO) was used, which aims to make translation to languages other than English possible such that the translated versions retain conceptual equivalence in each of the countries and cultures. The tool should be natural, acceptable, and applicable in practically the same form as the original. ${ }^{12}$

In the first stage, two health professionals and a language professor, whose native language is English and who are fluent in Brazilian Portuguese, independently performed three translations from English to Brazilian Portuguese. The translators were considered blind from each other. These professionals were selected for their familiarity with the constructs used by the tool. The professionals were asked to make an effort to maintain the semantic consistency of the terms and constructions used.

In stage 2, three bilingual Brazilian health professionals, independently and without knowledge of the original scale, performed back-translations of the first translations to English.
In stage 3, the authors of this study conducted an evaluation of semantic equivalence and the preliminary Brazilian Portuguese version was revised by consensus based on the translations and backtranslations, resulting in the version in Appendix 1. All the translators agreed with the conversion of one mile to 1600 meters (question 9) to facilitate understanding of the unit of distance.

In stage 4, this version was presented to 15 individuals (8 females and 7 males) ranging in age from 20 to 50 years old, 4 of whom had an elementary school education, 8 with a high school education, and 3 with a college education. In all cases, the interviewees were questioned about their comprehension of the questions and the clarity of the alternatives. All participants stated and demonstrated that they understood all the questions and that they were simple, objective, and easy to understand. The final version of the BPFS for Brazilian Portuguese was prepared from these considerations (Appendix 1).

After this process, the final version was used for 90 patients at the Toledo unit of the Clínica Escola de Fisioterapia da Universidade Paranaense. The selected participants were duly informed about the objective of the study and voluntarily signed the Informed Consent Form, agreeing to participate in it. The inclusion criteria were individuals of both sexes from 18 to 60 years of age who had been experiencing chronic specific or non-specific low back pain for more than 3 months.

Other studies using the BPFS ${ }^{11,13}$ were consulted for sample calculation via factor analysis. The original study that validated the BPFS used a sample of 77 individuals ( 47 females and 30 males)..$^{11}$ Samples of approximately 100 individuals are sufficient for conducting an exploratory factor analysis. ${ }^{14}$ It is also noteworthy that the consensus in the literature is that the stability levels in exploratory analysis depend on the quality of the psychometric tool and not to the sample size. ${ }^{15}$

The characteristics of the study sample are presented descriptively in Table 1.

Dimensionality was evaluated using exploratory factor analysis by the principal component analysis technique with varimax rotation. The number of factors was determined by examining the slope on the sedimentation graph. Reliability was analyzed using Cronbach's alpha coefficient. Because of the lack of a gold standard tool, two tools were used to evaluate construct validity between these and the BPFS by means of the Spearman's correlation coefficient. One of them was the Roland Morris Questionnaire, which consists of 24 questions related to common everyday situations in which patients may have difficulty performing due to the presence of low back pain. For each answer marked as true a point is added, such that the sum of the points can vary from 0 to 24 . Thus, the greater the number of questions marked as true, the greater the disability of the patient. The validity and reproducibility of the translated, adapted Portuguese version are well-established in the literature. ${ }^{9}$ The other tool used in this study was the Quebec Back Pain Disability Scale, ${ }^{16}$ developed to measure functional disability resulting from low back

Table 1. Sample characteristics.

\begin{tabular}{c|c|c}
\hline Sex & $\mathbf{N}$ & $\%$ \\
\hline Female & 75 & 83.3 \\
\hline Male & 15 & 16.7 \\
\hline Race & & \\
\hline Mhite & 63 & 70 \\
\hline Marital Status & 27 & 30 \\
\hline Married & & \\
\hline Divorced & 57 & 63.3 \\
\hline Single & 12 & 13.3 \\
\hline Stable union & 18 & 20 \\
\hline Education & 3 & 3.3 \\
\hline Elementary incomplete & & \\
\hline Elementary complete & 12 & 13.3 \\
\hline High school incomplete & 9 & 10.0 \\
\hline High school complete & 3 & 3.3 \\
\hline College incomplete & 30 & 33.3 \\
\hline College complete & 15 & 10.0 \\
\hline Graduate school & 12 & 13.3 \\
\hline
\end{tabular}


pain and composed of 20 questions that describe the difficulty performing activities of low intensity. It is based on a six-point scale $(0-5)$, where 0 is the absence of difficulty and 5 is the maximum inability to perform the activity. The final score ranges from 0 to 100 points and the higher the score, the worse the clinical condition. The tool is validated for Brazil. ${ }^{17}$

\section{RESULTS}

The final version of the BPFS was applied to 90 individuals of both sexes (75 females and 15 males) with a mean age of $45.8 \pm 11.8$ years and mean body mass index of $29.2 \pm 5.9 \mathrm{~kg} / \mathrm{m}^{2}$, who volunteered to participate in the study. The overall BPFS score for the sample was $33.4 \pm 15$ points. The male subjects had statistically higher scores than the females at $44.4 \pm 9$ and $31.2 \pm 15$ points, respectively ( $p>0.05$, Mann-Whitney $U$ test).

The mean values for each individual component are shown in Table 2.

In the simultaneous factor analysis of all the variables, the KaiserMeyer-Olkin (KMO) test yielded a value of 0.925 , indicating that this analysis is perfectly adequate for the treatment of the data. Bartlett's sphericity test, based on the Chi-squared statistical distribution, showed a result of 2441.009 for a significance level less than 0.001 , which allowed us to reject the null hypothesis that there was no correlation among the data analyzed. When analyzing the communalities, it was observed that all the questions of the tool had values greater than 0.50 by the extraction method. Therefore, it was not necessary to extract any component.

Initially the eigenvalues that represented the variability of each component and the percentage of variance explained by means of each one were identified, as can be seen in Table 3.

As a criterion for deciding the number of factors to be selected to represent the latent structure of the data, the latent root criterion, which selects only eigenvalues greater than 1, was initially considered. When considering this criterion, it was observed that a single factor corresponded to $91.39 \%$ of the total variability. This result is also satisfactory for the percentage of variance criterion, which suggests that a minimum explanation of $60 \%$ variability is sufficient.

Also in Table 3, the factor loadings that represent the contribution of each variable to the formation of component 1 , are presented. Varimax rotation was performed with Kaiser factor normalization to facilitate visualization of the representative factor loadings in each factor.

Cronbach's alpha test was used for internal BPFS consistency. All the correlations between the items were positive and significantly different from zero, which indicates that a scale can be built with these items, since they measure the same attribute. In the present study, the Cronbach's alpha value obtained was 0.990 .

Finally, the validity of the construct was tested by means of

Table 2. Average scores obtained in the BPFS

\begin{tabular}{c|c|c|c|c}
\hline $\mathbf{N}^{\mathbf{0}}$ & Question (approved final version) & Mean & $\begin{array}{c}\text { Standard } \\
\text { Deviation }\end{array}$ & $\mathbf{N}$ \\
\hline 1 & $\begin{array}{c}\text { Your normal work, housework, or school } \\
\text { activities }\end{array}$ & 2.90 & 1.65 & 90 \\
\hline 2 & $\begin{array}{c}\text { Your usual hobbies, recreational activities, } \\
\text { or sports }\end{array}$ & 3.03 & 1.18 & 90 \\
\hline 3 & Perform heavy activities around the house & 2.70 & 1.25 & 90 \\
\hline 4 & Bend or stoop & 2.80 & 1.38 & 90 \\
\hline 5 & Put on shoes or socks & 2.77 & 1.12 & 90 \\
\hline 6 & Lift a box of groceries off the floor & 2.40 & 1.44 & 90 \\
\hline 7 & Sleep & 3.07 & 1.70 & 90 \\
\hline 8 & Remain standing for an hour & 2.57 & 1.15 & 90 \\
\hline 9 & Walk 1600m & 2.93 & 1.32 & 90 \\
\hline 10 & $\begin{array}{c}\text { Go up and down two flights of stairs } \\
\text { (approximately 20 steps) }\end{array}$ & 2.60 & 1.26 & 90 \\
\hline 11 & Remain seated for an hour & 2.70 & 1.17 & 90 \\
\hline 12 & Drive for an hour & 2.97 & 1.23 & 90 \\
\hline
\end{tabular}

For each question the responder has the following alternatives on a scale from 0 to 5 points: Unable to perform the activity (0), Extreme difficulty (1); Quite a bit of difficulty (2); Moderate difficulty(3); A little bit of difficulty (4); No difficulty (5).
Table 3. Total Explained Variance and Factor Loading.

\begin{tabular}{c|c|c|c|c}
\hline Component & Total & \% Variance & Cumulative \% & Factor Loading \\
\hline 1 & 10.968 & 91.397 & 91.397 & 0.978 \\
\hline 2 & 0.344 & 2.868 & 94.265 & 0.958 \\
\hline 3 & 0.178 & 1.484 & 95.749 & 0.963 \\
\hline 4 & 0.142 & 1.18 & 96.929 & 0.978 \\
\hline 5 & 0.103 & 0.857 & 97.786 & 0.952 \\
\hline 6 & 0.071 & 0.591 & 98.376 & 0.934 \\
\hline 7 & 0.067 & 0.557 & 98.933 & 0.972 \\
\hline 8 & 0.053 & 0.445 & 99.378 & 0.965 \\
\hline 9 & 0.026 & 0.218 & 99.596 & 0.975 \\
\hline 10 & 0.02 & 0.169 & 99.765 & 0.973 \\
\hline 11 & 0.016 & 0.137 & 99.902 & 0.925 \\
\hline 12 & 0.012 & 0.098 & 100 & 0.895 \\
\hline
\end{tabular}

Extraction method: Principal Component Analysis.

Spearman's correlation coefficient between the BPFS and the Quebec Back Pain Disability Scale $(r=-0.739)$ and the Roland Morris Questionnaire $(r=-0.867)$, revealing in both cases a strong correlation between the tools $(p<0.001)$.

\section{DISCUSSION}

The prevalence of low back pain has increased proportionally as the world population ages. ${ }^{3}$ Globally, the scientific community is dedicated to the early and accurate identification of this dysfunction mainly in low- and middle-income countries. ${ }^{18,1}$

In Brazil, the territorial expanse, the heterogeneity of the population, and the non-uniformity of studies make precise low back pain prevalence and incidence data analysis in the population difficult, ${ }^{5}$ however, it is clear that this dysfunction has significantly impacted the healthcare and pension systems of the country. ${ }^{19}$ In this regard, in recent years the costs of healthcare and lost productivity due to low back pain have been substantial with social/social security costs reaching US\$2.2 billion. ${ }^{20}$

Despite various initiatives to address low back pain as a public health issue, ${ }^{21}$ specific strategies related to cost effectiveness and the management of this condition and its consequences still need to be identified. ${ }^{1}$

Related specifically to low back pain, we highlight the use in Brazil of the Quebec Low Back Disability scale and the Roland Morris Questionnaire, both validated for the Portuguese language. ${ }^{22}$ The present study offers the alternative of a tool with fewer questions that maintains the intended sensitivity and specificity. ${ }^{11,23}$

The present study succeeded in developing a Brazilian Portuguese version of the BPFS, following the parameters for transcultural tool adaptation recommended by the $\mathrm{WHO} .{ }^{12}$ The BPFS proved to be a tool that is easy for individuals with low back pain at different educational levels to understand, useful for this purpose, and with a reduced application time.

The mean BPFS score of the study sample was $33.4 \pm 15$ points. Similar results can be found in the original tool validation studies, which reported an initial evaluation value of $34.1 \pm 13$ points, ${ }^{11}$ as well as in a similar validation study where a value of $33.0 \pm 9.9$ points was reported. ${ }^{13}$

The adequacy of the factor analysis was confirmed by means of KMO and Bartlett's sphericity tests and made it possible to verify the suitability of the data to the application of factor analysis. In the present study, factor analysis proved to be adequate for the treatment of data with two factors, explaining the approximately $91.3 \%$ variance found. No other factor presented an eigenvalue greater than 1. The KMO test, which verifies the degree of intercorrelation among the variables, generated a value of 0.925 , suggesting good adaptation of the data to factor analysis. The values obtained in this test varied from 0 to 1 . The closer to 1 , the more suitable the sample is to the application of factor analysis. ${ }^{24}$

The internal consistency among the twelve BPFS questions was tested using Cronbach's alpha test, which generated a value equal to 0.99 indicating the high reliability of the responses attributed to the questions. Cronbach's alpha coefficient is one of the most used 
psychometric indicators to determine the reliability or internal validity of a tool. This study obtained higher values than those of the original study, which reported an internal consistency value of $0.93 .{ }^{11}$ In an Iranian sample, it was possible to determine a value of 0.895 . $^{13}$

Spearman's correlation analysis revealed strong linearity between the BPFS and the Roland Morris Questionnaire $(r=-0.74, p<0.05)$ and between the BPFS and the Quebec Back Pain Disability Scale $(r=-0.87 p<0.05)$, indicating robustness in the validity of the construct.

\section{CONCLUSION}

This study aimed to analyze the psychometric characteristics of the Brazilian version of the BPFS, a tool developed to evaluate functionality in patients with low back pain, through the analysis of the distribution of items, the study of dimensionality and internal consistency, and confirmatory factor analysis.

The results obtained were compatible with the original study to develop and validate for English. The question response time was short. Gaining consensus among the parties involved around terms related to the translation was easy and the back-translation was consistent with the original items.

The questionnaire validation process has peculiar and complex aspects. In this study, the BPFS had to be translated and adapted to Brazilian culture with the care necessary to allow individuals with different education levels to be able to understand it without changing the meaning of the questions.

By following all the previously defined guidelines, from translation to application to a Brazilian sample, it was possible to obtain results that proved the validity of the Brazilian version of the WEMWBS.

All authors declare no potential conflict of interest related to this article.

CONTRIBUTION OF THE AUTHORS: Each author made significant individual contributions to this manuscript. JJAS: design of the entire research project, statistical analysis, writing and final approval. FLAT and APK data collection and tabulation and final review of the article.

\section{REFERENCES}

1. Hartvigsen J, Hancock MJ, Kongsted A, Louw Q, Ferreira ML, Genevay S, et al. What low back pain is and why we need to pay attention. Lancet. 2018;391(10137):235667. doi:10.1016/S0140-6736(18)30480-X

2. Walker BF. The prevalence of low back pain: A systematic review of the literature from 1966 to 1998. J Spinal Disord. 2000;13(3):205-17. doi:10.1097/00002517-200006000-00003

3. Hoy D, Bain C, Williams G, March L, Brooks P, Blyth F, et al. A systematic review of the global prevalence of low back pain. Arthritis Rheum. 2012;64(6):2028-37. doi:10.1002/art.34347

4. Wu A, March L, Zheng X, Huang J, Wang X, Zhao J, et al. Global low back pain prevalence and years lived with disability from 1990 to 2017: estimates from the Global Burden of Disease Study 2017. Ann Transl Med. 2020;8(6):299. doi:10.21037/ atm.2020.02.175

5. Nascimento $P$, Costa L. Low back pain prevalence in Brazil: a systematic review. Cad Saude Publica. 2015;31(6):1141-56. doi:10.1590/0102-311X00046114

6. MacNeela P, Doyle C, O'Gorman D, Ruane N, McGuire BE. Experiences of chronic low back pain: a meta-ethnography of qualitative research. Health Psychol Rev. 2015;9(1):63-82. doi:10.1080/17437199.2013.840951

7. Fairbank JC, Couper J, Davies JB, O'Brien JP. The Oswestry low back pain disability questionnaire. Physiotherapy. 1980;66(8):271-3.

8. Vigatto R, Alexandre NMC, Correa Filho HR. Development of a Brazilian Portuguese version of the Oswestry Disability Index: Cross-cultural adaptation, reliability, and validity. Spine (Phila Pa 1976). 2007;32(4):481-6. doi:10.1097/01.brs.0000255075.11496.47

9. Nusbaum L, Natour J, Ferraz MB, Goldenberg J. Translation, adaptation and validation of the Roland-Morris questionnaire--Brazil Roland-Morris. Braz J Med Biol Res. 2001;34(2):20310. doi:10.1590/S0100-879X2001000200007

10. Poletto PR, Gobbo DKP, Gotfryd AO, Catania SN, Sousa DC, Pereira SBS. Cultural adaptation, reliability and validity of Japanese Orthopaedic Association Back Pain Evaluation Questionnaire to Brazilian Portuguese. Einstein (São Paulo). 2017;15(3):313-21. doi:10.1590/S1679-45082017A03890

11. Stratford PW, Binkley JM, Riddle DL. Development and initial validation of the back pain functional scale. Spine (Phila Pa 1976). 2000;25(16):2095-102. doi: 10.1097/00007632 200008150-00015

12. WHO. Process of translation and adaptation of instruments. 2013 [Accessed in??]. Available in: http://www.who.int/substance_abuse/research_tools/translation/en/.
13. Ansari NN, Naghdi S, Habibzadeh F, Salsabili N, Ebadi S. Persian translation and validation of the Back Pain Functional Scale. Physiother Theory Pract. 2018;34(3):223 30. doi:10.1080/09593985.2017.1390804

14. Hair JF, Anderson RE, Tatham RL, Black WC, Babim BJ. Multivariate Data Analysis. Prentice hall. 1998;5(3):207-19. doi:10.1016/j.jpharm.2011.02.019

15. MacCallum RC, Widaman KF, Zhang S, Hong S. Sample size in factor analysis. Psycho Methods. 1999;4(1):84-99. doi:10.1037/1082-989X.4.1.84

16. Kopec JA, Esdaile JM, Abrahamowicz M, Abenhaim L, Wood-Dauphinee S, Lamping DL, et al. The quebec back pain disability scale measurement properties. Spine (Phila Pa 1976) 1995;20(3):341-52. doi:10.1097/00007632-199502000-00016

17. Rodrigues MFP. Validação e adaptação Trans-cultural do Questionário de Quebec para Lombalgia. Santa Catarina. Universidade do Oeste de Santa Catarina-UNOESC; 2007.

18. Nordin M, Randhawa K, Torres P, Yu H, Haldeman S, Brady O, et al. The Global Spine Care Initiative: a systematic review for the assessment of spine-related complaints in populations with limited resources and in low- and middle-income communities. Eur Spine J. 2018;27(Suppl 6):816-27. doi: 10.1007/s00586-017-5446-3

19. Filho NM, Silva GA. Invalidez por dor nas costas entre segurados da Previdência Social do Brasil. Rev Saude Publica. 2011;45(3):494-502. doi:10.1590/S0034-89102011000300007

20. Carregaro RL, Tottoli CR, Rodrigues DS, Bosmans JE, da Silva EN, van Tulder M. Low back pain should be considered a health and research priority in Brazil: Lost productivity and healthcare costs between 2012 to 2016. PLoS One. 2020;15(4):e0230902. doi:10.1371/journal.pone.0230902

21. Ferreira G, Costa LM, Stein A, Hartvigsen J, Buchbinder R, Maher CG. Tackling low back pain in Brazil: a wake-up call. Brazilian J Phys Ther. 2019;23(3):189-95. doi:10.1016/j.bjpt.2018.10.001

22. Falavigna A, Teles AR, De Braga GL, Barazzetti DO, Lazzaretti L, Tregnago AC. Instruments of clinical and functional evaluation in spine surgery. Coluna/ Columna. 2011;10(1):62-7. doi:10.1590/S1808-18512011000100012

23. Stratford PW, Binkley JM. A comparison study of the back pain functional scale and Roland Morris Questionnaire. North American Orthopaedic Rehabilitation Research Network. J Rheumatol. 2000;27(8):1928-36.

24. Williams B, Onsman A, Brown T. Exploratory factor analysis: A five-step guide for novices. J Emerg Prim Heal Care. 1996;19(May):42-50. doi:10.1080/09585190701763982

Appendix 1. Brazilian Version of the Back Pain Functional Scale (Stratford et al. 2000)

Please select the appropriate response to each statement.

\begin{tabular}{|c|c|c|c|c|c|c|c|}
\hline & \multirow[t]{2}{*}{ Activity } & $\begin{array}{c}\text { Unable to Perform } \\
\text { the activity }\end{array}$ & $\begin{array}{l}\text { Extreme } \\
\text { Difficulty }\end{array}$ & $\begin{array}{c}\text { Quite a bit of } \\
\text { Difficulty }\end{array}$ & $\begin{array}{l}\text { Moderate } \\
\text { Difficulty }\end{array}$ & \begin{tabular}{|c|} 
A little bit \\
of difficulty
\end{tabular} & $\begin{array}{c}\text { No } \\
\text { Difficulty }\end{array}$ \\
\hline & & 0 & 1 & 2 & 3 & 4 & 5 \\
\hline 1 & Your normal work, housework, or school activities & & & & & & \\
\hline 2 & Your usual hobbies, recreational activities, or sports & & & & & & \\
\hline 4 & Bend or stoop & & & & & & \\
\hline 5 & Put on shoes or socks & & & & & & \\
\hline 6 & Lift a box of groceries off the floor & & & & & & \\
\hline 9 & Walk $1600 \mathrm{~m}$ & & & & & & \\
\hline 10 & Go up and down two flights of stairs (approximately 20 steps) & & & & & & \\
\hline 11 & Remain seated for an hour & & & & & & \\
\hline 12 & Drive for an hour & & & & & & \\
\hline
\end{tabular}

